\title{
Pengelolaan limbah elektronika di DKI Jakarta menggunakan pendekatan Soft System Methodology
}

\author{
D. Rimantho ${ }^{*}$ \\ 1Departemen Teknik Industri, Universitas Pancasila, Jakarta, Indonesia
}

\begin{abstract}
Abstrak
Pada beberapa dekade terakhir, pertumbuhan produk listrik dan elektronika mengalami peningkatan yang signifikan, ditandai dengan peningkatan permintaan dan penjualan produknya secara global. Hal ini mempengaruhi masa pakai produk menjadi lebih pendek, yang tentunya berakhir lebih cepat menjadi limbah. Beberapa faktor penyebab kompleksnya permasalahan pengelolaan limbah elektronika adalah peranan dan fungsi para stakeholder seperti pemerintah, sektor informal dan industri manufaktur, serta dinas kebersihan. Artikel ini bertujuan menganalisis permasalahan pengelolaan limbah elektronik dan alternatif pemecahannya melalui model pengelolaan limbah dengan pendekatan Soft System Methodology (SSM). Data dan informasi sistem pengelolaan limbah elektronika diperoleh melalui studi literatur dan diskusi mendalam dengan beberapa pakar. Hasil studi menunjukkan bahwa pengaplikasian metode SSM menghasilkan model konseptual yang mengilustrasikan aktivitas antar sub elemen guna memperbaiki pengelolaan limbah elektronika. Model ini dibangun untuk meningkatkan pengelolaan limbah dan mengurangi potensi dampak negatifnya. Relevansi peran dan sinergi para pelaku seperti pemerintah pusat, pemerintah daerah, pelaku usaha (usaha limbah, termasuk pemulung) menentukan keberhasilan tujuan. Sebagai pemangku kepentingan utama, Kementerian Lingkungan Hidup dan Kehutanan berperan dalam merancang kebijakan dan program. Hal ini dapat didukung oleh Kementerian Perindustrian, Dinas
\end{abstract} Abstract.

In the last few decades, the growth of electrical and electronic products has significantly increased, marked by an increase in demand and sales of its products globally. It affects the product's service life to be shorter, which ends up becoming waste faster. Some factors causing the complexity of electronic waste management problems are the roles and functions of stakeholders (government, informal sector, manufacturing industry and sanitation office). This article analyzed the electronic waste management problems and alternative solution through the waste management model using the Soft System Methodology (SSM) approach. Data and information were obtained through literature studies and in-depth discussions with several experts. The study results show that applying the SSM method produces a conceptual model illustrating the activities between subelements to improve electronic waste management. The SSM model was built to improve waste management and reduce its negative impacts. The role relevance and synergy of actors such as the central government, local governments, and business actors (waste businesses, including scavengers) determine the objectives' success. As a major stakeholder, Ministry of Environment and Forestry plays a role in designing policies and programs, supported by Ministry of Industry, DKI Jakarta Sanitation Service and other related agencies.

Keywords: e-waste, SSM, management, stakeholder

Kata kunci: limbah elektronika, SSM, manajemen, stakeholder

\section{PENDAHULUAN}

Peralatan listrik dan elektronik memberikan pengaruh signifikan pada kehidupan manusia dalam beberapa dekade terakhir. Peningkatan inovasi teknologi peralatan elektronika membuat kehidupan manusia menjadi lebih mudah, baik di rumah maupun di kantor. Hal ini menjadikan kehidupan masyarakat tidak dapat dipisahkan dari peralatan elektronika. Kemajuan yang sangat cepat dalam inovasi teknologi membuat masa penggunaan perlengkapan listrik dan elektronika menjadi lebih singkat dan berakhir lebih cepat menjadi

\footnotetext{
${ }^{*}$ Korespondensi Penulis

Email : dino.rimantho@univpancasila.ac.id
} 
limbah. Dengan demikian, peningkatan pembuatan produk elektronika akan memberikan dampak penting terhadap laju timbulan limbah elektronika.

Limbah elektronika adalah seluruh produk elektrikal dan elektronika yang telah melalui batas usia pakainya (Sthiannopkao and Wong 2013). Perangkat elektrikal dan elektronika dapat terdiri dari berbagai macam bentuk atau jenis tergantung dari penggunaannya. Uni Eropa membagi perangkat elektronika ke dalam sepuluh jenis yaitu perlengkapan rumah tangga besar, alat-alat rumah tangga kecil, teknologi informasi dan peralatan telekomunikasi, peralatan konsumen, peralatan pencahayaan, alat-alat listrik dan elektronik, mainan, sistem peralatan medis, pemantauan instrumen kontrol dan dispenser otomatis (European Commission-WEEE Directive 2003).

Produksi peralatan listrik dan elektronika di negara-negara maju mengalami pertumbuhan yang sangat signifikan dibandingkan dengan produk lainnya (Hilty 2005). Menurut Pariatamby and Victor (2013), limbah elektronika di Uni Eropa mengalami peningkatan sekitar 3-5\% per tahun atau tiga kali lebih cepat dibandingkan laju timbulan limbah padat rumah tangga. UNEP (2006) juga menyatakan bahwa peningkatan laju timbulan elektronika sekitar 3-5\% tiap tahunnya. Hal ini membentuk perkembangan aliran limbah tercepat di dunia. Schluep et al. (2009) meramalkan bahwa laju timbulan elektronika secara garis besar adalah 40 juta ton per tahun. Sementara itu, beberapa peneliti juga melaporkan bahwa peningkatan laju timbulan elektronika terjadi di beberapa Negara di Asia seperti Taiwan, China, Filipina, Korea dan India (Peralta and Fontanos 2006; Terazono et al. 2006). Penelitian yang dilakukan oleh Rimantho et al. (2019) melaporkan bahwa timbulan limbah elektronika di DKI Jakarta sebesar $7.713,42 \mathrm{~kg} /$ tahun atau 4,04 kg/orang/tahun. Studi tersebut dilakukan pada 400 rumah tangga dan 54 sektor informal.

Limbah elektronika memberikan dampak negatif pada semua aspek kehidupan baik pada lingkungan maupun perekonomian masyarakat. Namun demikian, limbah elektronika juga masih memiliki potensi ekonomi yang tidak kecil. Potensi ekonomi yang diperoleh dari daur ulang limbah elektronika adalah logam mulia seperti emas, perak, paladium, tembaga, aluminium, besi dan plastik (Hosoda 2007; Kahhat et al. 2008; Prakash and Manhart 2010).

Limbah memiliki ancaman serius terhadap lingkungan dan kesehatan manusia karena belum ada teknologi ramah lingkungan pada proses daur ulangnya. Permasalahan ini semakin dipersulit dengan belum adanya tempat pembuangan khusus untuk limbah elektronika. Terdapat dua hal yang menjadi penyebab munculnya masalah lingkungan dan ekonomi dari pengelolaan limbah elektronika. Pertama, adanya kandungan senyawa berbahaya dalam limbah elektronika yang memiliki dampak negatif pada alam. Kedua, adanya faktor keterbatasan dalam menyerap residu limbah elektronika di lingkungan. Jika 
terjadi perbedaan kapasitas, maka akan mendorong munculnya risiko serius pada stabilitas dan batas toleransi ekosistem. Misalnya, efek proporsional dari merkuri pada pencemaran air yang kecil dalam standar pencemaran yang masih rendah. Di sisi lain, pada tingkatan konsentrasi yang tinggi maka pengaruhnya juga akan sangat tinggi. Menurut Perman et al. (2003) pencemaran senyawa merkuri akan membuat perubahan fungsi dari ekosistem dan menurunkan kapasitas penyerapan dari lingkungan.

Proses daur ulang limbah elektronika banyak dilakukan di sektor informal, sehingga memunculkan potensi kerusakan lingkungan dan penurunan kualitas kesehatan masyarakat (Wang et al. 2012). Secara umum, munculnya risiko dan ancaman serius bagi lingkungan dan kesehatan masyarakat diakibatkan dari penggunaan peralatan dan metode yang sangat sederhana dalam proses daur ulang limbah elektronika, umumnya terjadi di negara-negara berkembang (Prakash and Manhart 2010; Ongondo et al. 2011). Contoh metode sederhana tersebut adalah pembongkaran fisik menggunakan peralatan sederhana seperti palu, obeng dan pahat (Wen et al. 2006; Amoyaw-Osei et al. 2011), pelepasan komponen dari papan sirkuit dengan metode pemanasan (Puckett et al. 2002), pelepasan logam mulia menggunakan larutan asam (Wong et al. 2007), pemecahan dan pendaur-ulangan plastik (Wong et al. 2007), pembakaran kabel untuk mengambil tembaga (Wong et al. 2007) dan pengisian ulang kartrid toner (Puckett et al. 2002).

Penelitian yang dilakukan oleh Sudarmaji et al. (2006) menggarisbawahi penurunan kualitas kesehatan manusia disebabkan adanya senyawa berbahaya dari limbah elektronika. Robinson (2009) juga melaporkan bahwa senyawa Arsenik (As) berpotensi menyebabkan penurunan kesehatan seperti gangguan mata, kulit, darah dan lever. Selain itu, jalur masuknya zat pencemar limbah elektronika pada manusia adalah melalui makanan, udara, dll. Sebuah penelitian di daerah pembongkaran printer di Provinsi Guiyu, China menunjukkan bahwa para pekerja membongkar kartrid toner dengan peralatan sederhana tanpa alat pelindung diri yang sesuai. Pembongkaran toner tersebut berpotensi mengganggu sistem pernafasan manusia dan menyebabkan kanker (Huo et al. 2007). Lebih lanjut, hasil penelitian Rimantho et al. (2020) menunjukkan beberapa nilai RPN tertinggi antara lain teknologi manual (729), jumlah teknologi (729), kepatuhan hukum (729) dan biaya daur ulang (729).

Kompleksitas masalah pengelolaan limbah elektronik memerlukan pendekatan yang berbeda. Oleh karena itu, artikel ini bertujuan merancang model pengelolaan limbah elektronik berkelanjutan dengan pendekatan soft system methodology yang terkait dengan peran institusi, pelaku dan rules of the game pengelolaan limbah elektronik di Provinsi DKI Jakarta, Indonesia. 


\section{METODOLOGI}

Sebuah pendekatan berpikir sistematis (system thinking) dapat diaplikasikan dalam menjawab suatu permasalahan yang belum terstruktur. Pendekatan ini dapat memberikan gambaran keterkaitan antar faktor dan kegiatan yang dilakukan, serta aktor-aktor yang berkepentingan sejak dari input hingga munculnya output. Melalui pendekatan ini, dapat diketahui pula interaksi dari unsur, komponen dan sub sistem yang menyusun sebuah sistem. Pendekatan berpikir sistem meliputi beberapa hal seperti proses berpikir, hasil akhir dan target yang ada (Eriyatno 2012).

Dalam artikel ini, soft system methodology (SSM) diaplikasikan sebagai sebuah metode sistem yang memberikan ilustrasi tentang kondisi permasalahan yang sedang dihadapi. Metode SSM adalah suatu teknik soft system thinking yang dikenalkan oleh Checkland (1999). Metode SSM memiliki perbedaan dengan pendekatan hard system methodology. Metode ini lahir karena adanya cara pandang bahwa dasar pembuatan suatu sistem lebih mengarah pada permasalahan yang memiliki karakteristik sangat abstrak atau tidak jelas (Purnomo 2012). Lebih jauh, Checkland (1999) menggunakan tujuh tahapan dalam mengaplikasikan metode SSM seperti yang ditunjukkan pada Gambar 1.

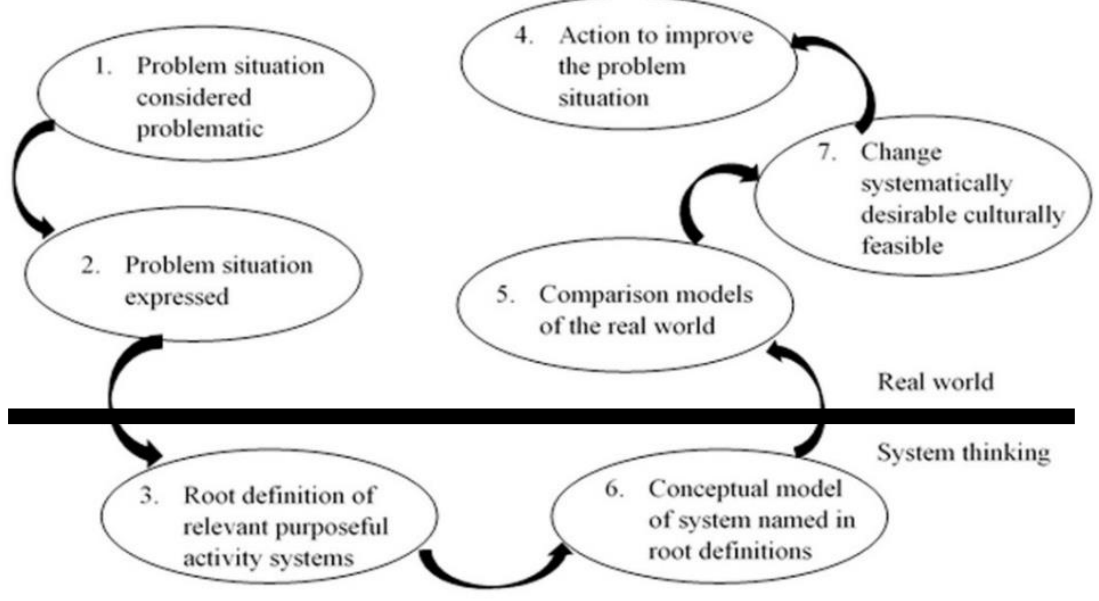

Gambar 1. Checkland protokol.

Penyusunan model pengelolaan limbah elektronika yang berkelanjutan di DKI Jakarta pada artikel ini dilakukan melalui tujuh tahapan yang mengacu pada Checkland Protokol dengan uraian sebagai berikut:

1) Analisis yang menguraikan kondisi/situasi yang tepat dalam perspektif pengelolaan limbah elektronika. Langkah awal adalah menanyakan problem yang harus dijawab terkait pengelolaan limbah elektronika yang juga diarahkan pada dampak lingkungan, sosial dan ekonomi. 
2) Pemahaman terhadap problem apa saja yang dihadapi oleh seluruh stakeholder. Pemahaman ini meliputi keperluan apa saja yang menjadi kebutuhan pihak stakeholder. Selain itu, pemahaman juga didasarkan pada kapasitas dan responsibilitas para stakeholder. Output dari pemahaman ini adalah ilustrasi keterlibatan rangkaian dari masing-masing stakeholder atau secara umum disebut rich picture.

3) Membuat pengertian posisi masing-masing stakeholder dengan mengaplikasikan suatu metode yang disebut CATWOE (Client or Customers, Actors, Transformations, Weltanschauung, Owner dan Environment constrain).

4) Membuat desain maya atau konseptual yang akan memberikan uraian ketergantungan antar kegiatan atau operasi. Desain maya ini mengilustrasikan korelasi dari input-proses-output dari satu kegiatan dengan kegiatan lainnya.

5) Membuat susunan program aktivitas yang akan diterjemahkan dalam aksi dan secara umum membuat komparasi antara kondisi aktual dengan desain transdental yang telah didesain.

6) Membuat interpretasi perbedaan yang berpotensi untuk dilakukan. Kontroversi antar ahli berpotensi terjadi pada fase ini. Kemungkinan modifikasi pada beberapa hal berpotensi terjadi seperti berubahnya strategi kebijakan, peralihan komposisi dan kemungkinan peralihan prinsip dan budaya dalam wujud peralihan kaidah berasumsi.

7) Membuat pelaksanaan aksi pembaruan pada desain yang telah dibuat.

\section{HASIL DAN PEMBAHASAN}

\subsection{Analisis situasional}

Pengelolaan limbah elektronika di Indonesia saat ini belum memiliki peraturan atau regulasi yang spesifik, sehingga berpotensi memunculkan permasalahan yang sangat rumit. Lebih lanjut, peningkatan laju limbah elektronika ditentukan oleh banyak faktor seperti tingkat pendidikan, kultur, tingkat pendapatan, daya beli masyarakat, dll. Dalam rangka meningkatkan pengelolaan limbah elektronika, diperlukan proses rekognisi dan pengenalan karakter limbah elektronika secara detail. Dengan mengetahui karakteristik limbah elektronika akan memberikan suatu kerangka mengenai jenis limbah elektronika, komposisi limbah serta sifat-sifat limbah. Selain itu, akan memberikan dukungan informasi kepada para stakeholder terkait mengenai siapa saja yang berpotensi memunculkan limbah elektronika. Karakterisasi juga dapat memunculkan perkiraan konsekuensi pada lingkungan dan untuk membuat keseimbangan efektivitas strategi pengendaliannya. 
Belum ada teknologi yang ramah lingkungan pada proses daur ulang yang dapat mencemari lingkungan seperti air, tanah dan udara. Permasalahan ini semakin dipersulit dengan belum adanya tempat pembuangan khusus limbah elektronika. Permasalahan pada pengelolaan limbah elektronika juga berpotensi semakin kompleks karena pemerintah belum memberikan perhatian secara khusus dan serius. Pengelolaan limbah elektronika saat ini masih menyatu dengan penanganan limbah bahan berbahaya dan beracun (B3). Penyebab lainnya adalah belum optimalnya pemerintah dan stakeholder dalam mengimplementasikan setiap kebijakan dan strategi yang terkait dengan pengelolaan dan penanganan limbah berwawasan lingkungan.

Pengelolaan limbah elektronika mempunyai tujuan memperkecil atau menghilangkan risiko-risiko terhadap kesehatan manusia dan lingkungan. Pengelolaan limbah elektronika dapat dikatakan baik apabila proses pengelolaannya tidak menyebabkan penurunan kualitas kesehatan manusia dan tidak merusak lingkungan sekitar. Dalam rangka meminimalisasi terjadinya risiko-risiko tersebut, perlu diciptakan suatu model manajemen risiko pada pengelolaan limbah elektronika yang berkelanjutan di DKI Jakarta. Mengacu pada deskripsi yang telah diuraikan sebelumnya, dapat diperoleh konklusi dari pengelolaan limbah elektronika sebagaimana yang ditunjukkan pada Gambar 2.

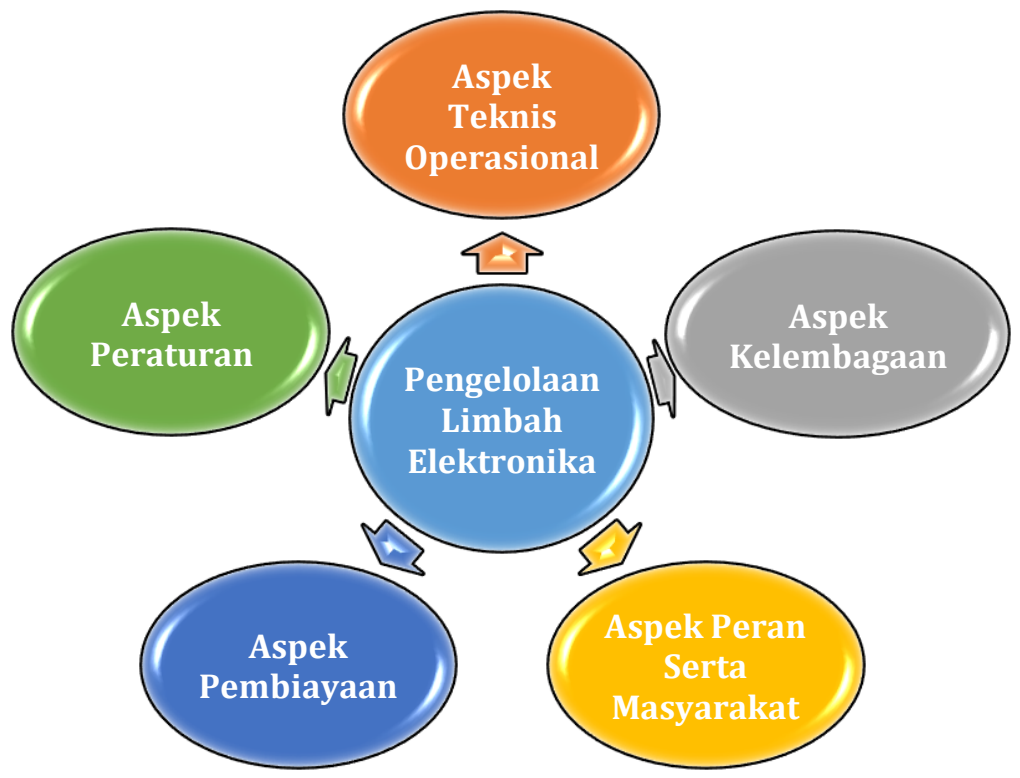

Gambar 2. Aspek-aspek dalam pengelolaan limbah elektronika.

Aspek hukum/peraturan belum mengatur secara spesifik pengelolaan limbah elektronika, sehingga masih perlu adanya regulasi pemerintah pusat maupun pemerintah Provinsi DKI Jakarta. Pada aspek kelembagaan, belum ada 
struktur organisasi kelembagaan untuk pengelolaan limbah elektronika. Berkaitan dengan aspek teknik dan operasional, belum ada tempat pembuangan khusus atau pusat daur ulang limbah elektronika yang menggunakan teknologi bersih dan diawasi oleh pemerintah, serta belum ada standar operasional dan prosedur pengelolaan limbah elektronika. Mengenai aspek pembiayaan, belum ada alokasi anggaran dan retribusi untuk limbah elektronika. Aspek keterlibatan penduduk dan sektor swasta menyangkut pemahaman publik dan investasi swasta dalam penyelenggaraan dan pengendalian limbah.

\subsection{Root definition permasalahan}

Munculnya persoalan manajemen limbah elektronika dari sudut pandang lingkungan, sosial dan ekonomi secara garis besar disebabkan oleh efek yang ditimbulkannya. Efek ini berpotensi memberikan pengaruh serius terhadap penurunan kualitas lingkungan dan kesehatan manusia, serta potensi konflik dan diskoordinasi antar lembaga. Berdasarkan hal tersebut, akan dijelaskan keterkaitan problematika yang dihadapi dari tingkat relevansi antar stakeholder. Dengan mengaplikasikan pendekatan CATWOE dapat diketahui dan dijelaskan relevansi tiap stakeholder dalam pengelolaan limbah elektronika, yang penjelasannya disampaikan secara rinci pada bagian berikut ini:

- Client atau konsumen adalah masyarakat dan pemulung yang berperan dalam menghasilkan laju timbulan limbah elektronika, serta konsumen akhir yang menggunakan produk elektronika. Masyarakat dan pemulung adalah sekumpulan masyarakat yang terdampak oleh luaran manajemen limbah yang dilaksanakan sektor informal daur ulang limbah elektronika.

- Actors adalah bagian yang mempunyai fungsi penting dalam memberikan efek baik secara ekonomi, lingkungan dan sosial. Komponen ini terdiri dari sektor informal daur ulang, instansi/organisasi yang terlibat dalam pengelolaan limbah elektronika, serta LSM pemerhati lingkungan. Kelompok ini memiliki kepekaan atas potensi perselisihan yang didasarkan pada perbedaan keinginan dari setiap stakeholder.

- Transformation process membutuhkan sebuah konsensus pada manajemen limbah elektronika yang mengacu pada hal-hal yang berkaitan dengan keberlanjutan lingkungan, sosial dan ekonomi.

- Weltanschauung merupakan bahasa Jerman yang berarti interpretasi yang harus menjadi dasar dalam pembuatan definisi yang memiliki arti dan sesuai dengan situasi kondisinya. Pada kasus perselisihan kepentingan dari faktor energi, pangan dan lingkungan, pada dasarnya belum ditemukan kesamaan persepsi yang dapat memberikan keseimbangan dari setiap stakeholder. Dengan demikian, perlu suatu ordinasi dan peraturan yang dapat menyelaraskan tingkat kebutuhan setiap pemangku kepentingan. 
- Owner merupakan seluruh komponen pengelola negara seperti Kementerian Lingkungan Hidup, Perindustrian dan Perdagangan. Pada tingkat daerah atau provinsi, komponen pengelola dalam konteks manajemen limbah elektronika antara lain Dinas Kebersihan dan Pertamanan dan BPLHD. Fungsi penting kelompok ini adalah menghasilkan suatu peraturan dan tahapan pelaksanaan dalam rangka manajemen limbah elektronika yang mengacu pada faktor-faktor keberlanjutan.

- Environment constrain adalah faktor yang berpotensi menghambat pelaksanaan kegiatan setiap pemangku kepentingan. Hambatan paling utama adalah tingkat pemahaman. Minimnya sosialisasi dari pemerintah membuat pemahaman tiap pemangku kepentingan menjadi berbeda. Sebagai hasilnya, peraturan yang telah dibuat tidak berjalan dengan optimal.

\subsection{Model konseptual}

Model konseptual merupakan ilustrasi keterkaitan dari masing-masing kegiatan dan fungsi setiap pemangku kepentingan dalam rangka pencapaian tujuan. Setiap fungsi mempunyai keterkaitan yang saling mengisi kekurangan masing-masing. Ilustrasi keterkaitan dari masing-masing stakeholder (rich picture) dan model konseptual dalam pengelolaan limbah elektronika ditunjukkan pada Gambar 3 dan Gambar 4.

Pada pengelolaan limbah elektronika masih ditemukan adanya keadaan dependensi dan tingginya keinginan yang justru menjadi titik awal terjadinya perselisihan. Terjadinya perselisihan ini pada hakikatnya merupakan gambaran belum adanya beberapa faktor dalam pengelolaan limbah elektronika seperti sistem pengumpulan, transfer, daur ulang dan pembuangan. Pengawasan terhadap kegiatan daur ulang oleh pemerintah juga belum ada. Di sisi lain, tingkat penggunaan produk elektronika cenderung meningkat seiring dengan penemuan teknologi baru dan peningkatan populasi.

Kontribusi nyata dari setiap pemangku kepentingan harus dilaksanakan dengan optimal. Pemerintah mempunyai fungsi penting dalam merumuskan dan membuat strategi dan regulasi yang mengutamakan semua komponen masyarakat dan didasarkan pada keberlanjutan lingkungan, ekonomi dan sosial. Hal tersebut akan menjadi panduan atau pedoman bagi seluruh pemangku kepentingan dalam pengendalian lingkungan dan manajemen limbah elektronika. Para aktor dalam hal ini sektor informal daur ulang dan sektor industri produk elektronika mempunyai fungsi dalam mengimplementasikan kebijakan. Pemantauan/pengendalian dapat dilakukan secara sinergi dengan pemangku kepentingan lainnya seperti wakil dari pemerintahan bidang lingkungan hidup, LSM, akademisi atau pemerhati lingkungan hidup. 


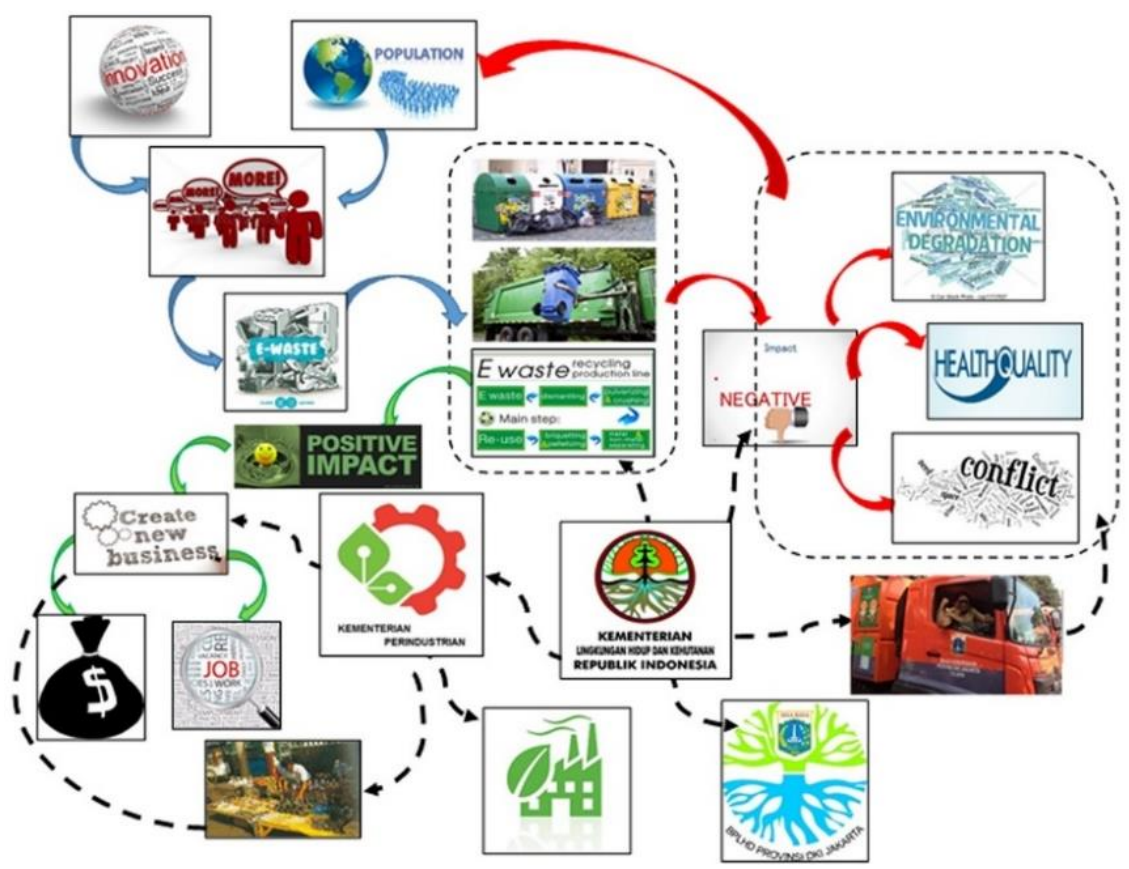

Gambar 3. Rich picture pengelolaan limbah elektronika.

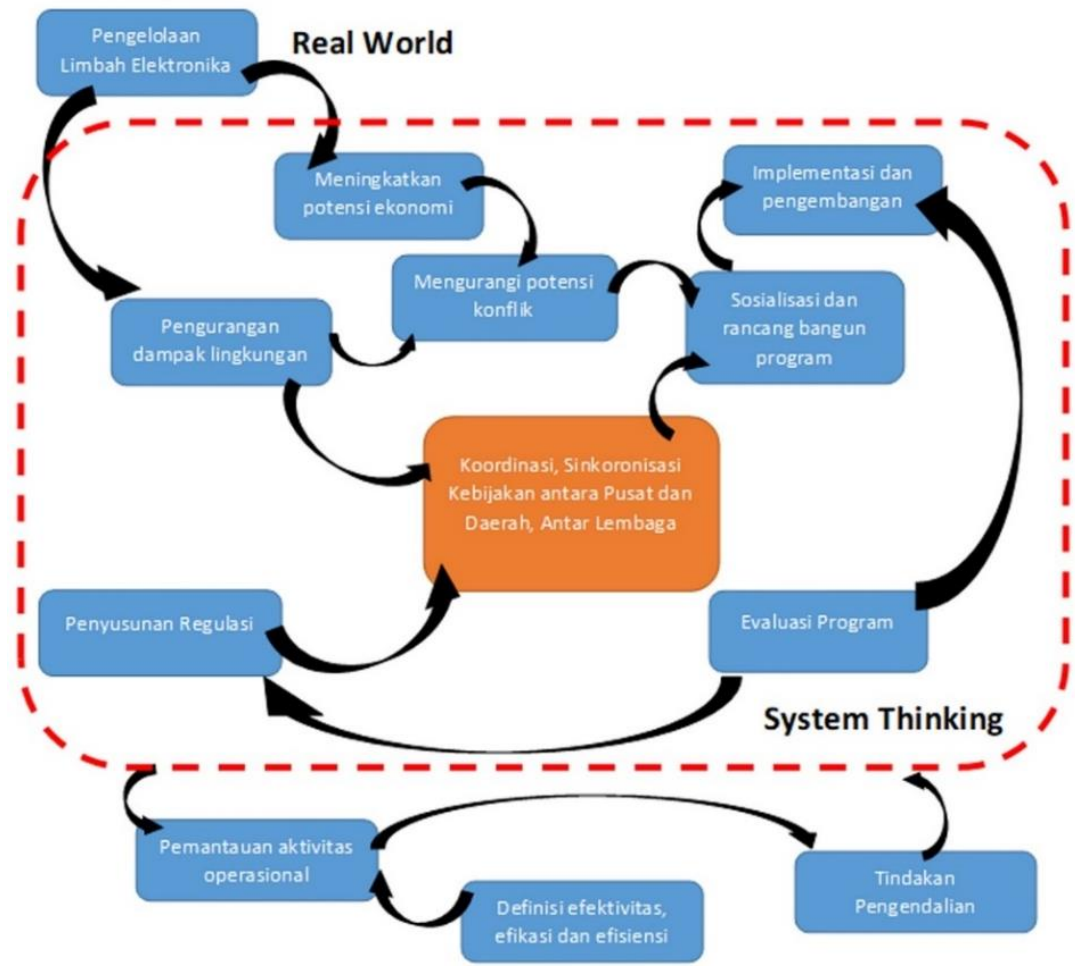

Gambar 4. Model konseptual pengelolaan limbah elektronika. 
Seluruh pemangku kepentingan perlu melaksanakan prosedur pengawasan pelaksanaan regulasi dan aksi nyata dari implementasi manajemen limbah elektronika. Oleh karena itu, perlu adanya parameter tingkat pemenuhan atas implementasi fungsi setiap pemangku kepentingan yang mengacu pada tiga aspek manajemen yaitu efisiensi, efikasi dan efektivitas. Parameter ini yang akan menjadi pedoman dalam pelaksanaan peningkatan proses yang dilaksanakan secara berkesinambungan. Lebih lanjut, pengelolaan limbah elektronika harus mengacu pada lima aspek yaitu aspek teknis operasional, peraturan dan regulasi, kelembagaan, pembiayaan dan peran serta masyarakat. Penerapan lima aspek ini akan mampu menjawab permasalahan yang berpotensi muncul baik dari sudut pandang lingkungan, ekonomi dan sosial.

\subsection{Perbandingan model dengan realita}

Dalam rangka mendeteksi implementasi dari desain sistem yang telah dibuat, dibutuhkan tahapan yang lebih rinci mengenai kajian komparasi antara tujuan yang diharapkan pada sistem dan kondisi riil di dunia nyata. Terdapat beberapa pendekatan yang dapat digunakan seperti:

1. Melaksanakan pencatatan secara informal dari temuan komparasi yang dilaksanakan.

2. Membuat penetapan dari kriteria komparasi secara formal yang selanjutnya diikuti oleh kegiatan assessment dan kajian dari terjadinya perbedaan target.

3. Melaksanakan simulasi sistem. Membuat suatu skema yang telah terlaksana di periode sebelumnya, selanjutnya melakukan skema berdasarkan desain yang telah dirancang yang kemudian membuat kajian dari desain tersebut.

4. Mengawasi apakah desain yang telah dirancang dapat berkontribusi pada solusi yang diinginkan.

\subsection{Perbaikan model}

Perubahan pada desain ditujukan untuk membuat kesamaan antara desain dengan dunia nyata. Perubahan yang dilaksanakan mengacu pada tingkat perbedaan yang ada. Disamping itu, desain model juga harus disesuaikan dengan kondisi di dunia nyata. Lebih lanjut, tujuan perubahan atas desain yang dibuat adalah untuk mencapai logically desirable dan cultural feasible. Kedua hal ini memiliki makna bahwa sebuah desain harus dapat memberikan solusi secara logis dan mengandung nilai kepatutan dari kenyataan yang ada.

\subsection{Implementasi model}

Dengan terpenuhinya desain yang didasarkan pada kualifikasi logis dan kepatutan, tahap berikutnya adalah melakukan implementasi untuk menemukan jawaban terbaik guna menjawab setiap keinginan. Pelaksanaan implementasi kegiatan ini dapat dilakukan melalui perubahan persepsi dan pemberian 
penafsiran dari setiap pemangku kepentingan dalam manajemen limbah elektronika terkait dengan makna penting dari efek pada lingkungan, ekonomi dan sosial. Selanjutnya, regulasi yang telah dibuat oleh pemerintah dijadikan pedoman dan panduan dalam implementasi oleh setiap pemangku kepentingan. Hal terakhir adalah penyusunan rancangan yang bersifat prediksi dan bayangan dari persoalan yang memunculkan variasi pemahaman yang berpotensi muncul saat pelaksanaan regulasi sebagai tahapan terakhir. Perselisihan ini berpotensi terjadi mengingat tingkat pemahaman yang berbeda dari setiap pemangku kepentingan. Dengan demikian, tahapan pemecahan masalah harus disetujui secara bersama saat terjadi perselisihan.

\section{KESIMPULAN DAN SARAN}

Peningkatan laju timbulan limbah elektronika menunjukkan kecenderungan yang signifikan di Provinsi DKI Jakarta. Pendekatan soft system methodology diaplikasikan untuk dapat mengelola limbah elektronika secara berkelanjutan baik dari sudut pandang lingkungan, ekonomi dan sosial. Dari pembuatan desain manajemen limbah elektronika, diperoleh simpulan bahwa terdapat perbedaan pada fungsi dan keinginan dari para pemangku kepentingan. Peningkatan laju timbulan limbah elektronika, proses daur ulang yang belum ramah lingkungan, serta belum adanya regulasi dan kelembagaan yang mengatur berpotensi memicu terjadinya konflik kepentingan antara aktor dan stakeholder. Perlu adanya skenario program pengelolaan limbah elektronika yang setidaknya mengacu pada lima aspek antara lain teknis operasional, peraturan dan regulasi, kelembagaan, pembiayaan dan peran serta masyarakat.

\section{DAFTAR PUSTAKA}

Amoyaw-Osei Y, Agyekum 00, Pwamang JA, Mueller E, Fasko R and Schluep M. 2011. Ghana e-waste country assessment [internet]. Tersedia di: https://ewasteguide.info/Amoyaw-Osei_2011_GreenAd-Empa.

Checkland P. 1999. An application of soft system methodology. In: Rosenhead J. Rational analysis for a problematical word. Wiley. Chichester.

Eriyatno. 2012. Ilmu sistem: meningkatkan integrasi dan koordinasi manajemen. Guna Widya. Bogor.

European Commission-WEEE Directive. 2003. Directive 2002/96/EC of the European parliament and of the council on waste electrical and electronic equipment (WEEE). European Commission. Brussels.

Hilty LM. 2005. Electrical waste-an emerging risk? Environmental Impact Assessment Review. 25(5):431-435. https://doi.org/10.1016/j.eiar.2005. 04.002 . 
Hosoda E. 2007. International aspects of recycling of electrical and electronic equipment: material circulation in the East Asian region. Journal of Material Cycles and Waste Management 9(2):140-150.

Huo X, Peng L, Xu X, Zheng L, Qiu B, Qi Z, Zhang B, Han D and Piao Z. 2007. Elevated blood lead levels of children in Guiyu, an electronic waste recycling town in China. Environmental Health Perspectives 115(7):11131117.

Kahhat R, Kima J, Xua M, Allenbya B, Williams E and Zhanga P. 2008. Exploring ewaste management systems in the United States. Resources, Conservation and Recycling 52(7):955-964.

Ongondo FO, Williams ID and Cherrett TJ. 2011. How are WEEE doing? a global review of the management of electrical and electronic wastes. Waste Management 31(4):714-730.

Pariatamby A and Victor D. 2013. Policy trends of e-waste management in Asia.

J. Mater. Cycles Waste Manag. 15:411-419. https://doi.org/10.1007/s10163 -013-0136-7.

Peralta GL and Fontanos PM. 2006. E-waste issues and measures in the J. Mater. Cycles Waste Manag. 8:34-39. https://doi.org/10.1007/s10163-005-01 42-5

Perman R, Ma Y, McGilvray J and Common M. 2003. Natural resource and environmental economics $3^{\text {rd }}$ Ed. Pearson Education Limited. Harlow.

Prakash S and Manhart A. 2010. Socio-economic assessment and feasibility study on sustainable e-waste management in Ghana [internet]. Tersedia di: https://www.oeko.de/oekodoc/1057/2010-105-en.pdf.

Puckett J, Byster L, Westervelt S, Gutierrez R, Davis S, Hussain A and Dutta M. 2002. Exporting harm: the high-tech trashing of Asia. The Basel Action Network (BAN) and Silicon Valley Toxics Coalition (SVTC). Seattle.

Purnomo H. 2012. Pemodelan dan simulasi untuk pengelolaan adaptif sumber daya alam dan lingkungan. IPB Press. Bogor.

Rimantho D, Noor E, Eriyatno dan Effendi H. 2019. Penilaian aliran limbah elektronika di DKI Jakarta menggunakan material flow analysis (MFA). Jurnal Ilmu Lingkungan 17(1):120-129.

Rimantho D, Noor E, Eriyatno and Effendi H. 2020. Risk assessment on failure factors of e-waste management process using FMEA method. International Journal on Advanced Science, Engineering and Information Technology 10(6): 2504-2511. http://dx.doi.org/10.18517/ijaseit.10.6.7433.

Robinson BH. 2009. E-waste: an assessment of global production and environmental impacts. Sci. Total Environ. 408(2):183-191.

Schluep M, Hagelüken C, Kuehr R, Magalini F, Maurer C, Meskers C, Muellera E and Wang F. 2009. Sustainable innovation \& technology transfer industrial 
sector studies: recycling - from e-waste to resources. United Nations Environment Programme (UNEP) and United Nations University (UNU). Paris.

Sthiannopkao S and Wong MH. 2013. Handling e-waste in developed and developing countries: initiatives, practices, and consequences. Sci. Total Environ. 463-464:1147-1153.

Sudarmaji, Mukono J dan Corie IP. 2006. Toksikologi logam berat B3 dan dampaknya terhadap kesehatan. Jurnal kesehatan Lingkungan 2(2):129142.

Terazono A, Murakami S, Abe N, Inanc B, Moriguchi Y, Sakai S, Kojima M, Yoshida A, Li J, Yang J, Wong MH, Jain A, Kim I, Peralta GL, Lin C, Mungcharoen T and Williams E. 2006. Current status and research on e-waste issues in Asia. J. Mater. Cycles Waste Manag. 8:1-12. https://doi.org/10.1007/s10163-005 $-0147-0$

[UNEP] United Nations Environment Programme. 2006. Overview: electrical and electronic equipment when becoming waste (e-waste) such as personal computers, printers, televisions, mobile phones, refrigerators and airconditioning units is one of the fastest growing waste streams in the world today [internet]. Tersedia di: http://www.basel.int.

Wang F, Huisman J, Meskers CEM, Schluep M, Stevels A and Hagelüken C. 2012. The best-of-2-worlds philosophy: developing local dismantling and global infrastructure network for sustainable e-waste treatment in emerging economies. Waste Management 32(11):2134-2146.

Wen XF, Li JH, Hao L, Yin FF, Hu LX, Liu HP and Liu ZY. 2006. An agenda to move forward e-waste recycling and challenges in China [Proceeding]. Proceedings of the 2006 IEEE International Symposium on Electronics and the Environment 315-320. https://doi.org/10.1109/ISEE.2006.1650083.

Wong MH, Wu SC, Deng WJ, Yu XZ, Luo Q, Leung AO, Wong CS, Luksemburg WJ and Wong AS. 2007. Export of toxic chemicals - a review of the case of uncontrolled electronic-waste recycling. Environmental Pollution 149(2):131-140. 